\title{
Morpho-Anatomical Analysis of Cosmostigma racemosum (Asclepiadoideae) Flowers
}

\author{
Widodo ${ }^{1,2 *}$, Mohamad Amin ${ }^{1}$, Mimien Henie Irawati Al-Muhdar ${ }^{1}$ and Muhammad Ja'far Luthfi ${ }^{2}$ \\ ${ }^{1}$ Biology Education-Graduate Program, State University of Malang. Jalan Semarang 5 Malang 65145, East Java, Indonesia \\ ${ }^{2}$ Faculty of Science and Technology, UIN Sunan Kalijaga. Jl. Marsda Adisucipto No.1 Yogyakarta 55281, Indonesia
}

Author correspondency*:

wwidodo594@gmail.com, phone: +6281548566820

\begin{abstract}
Cosmostigma racemosum is a plant species belonging to the family Apocynaceae, the subfamily Asclepiadoideae. Cosmostigma racemosum is found in Nglanggeran Mountain Gunungkidul, Yogyakarta. The local name and its original distribution are not known. Information or study of Cosmostigma racemosum in Indonesia is not available. Comprehensive characterization of this species is important for authentication and addition of data base. Characterization was conducted by analyzing the morphology and anatomy of flower. The objectives of this study were to describe and analyze the morphology and anatomy of $C$. racemosum flowers. The method of research was based on observation method and exploration of plant systematics evidence or taxonomy evidence, including analyses and description of morphology and anatomy of flower structure and its development. The results showed that the characteristics of flower morphology are in accordance with the existing description in literatures. Characteristics of pollinia are specific characters of morphological aspect of flower. Data of anatomy of flower and its parts development are the new ones which confirm the position of C.racemosum as a member of the tribe Marsdenieae. The data of anatomy also show new information of the ontogeny of the important parts of flower: pollinia formation, pollinia corpusculum, anther wall, anther sac, stigma, stamen, staminal tube, stigmatic chamber, and structure of ovary in Asclepiadoideae.
\end{abstract}

Keywords: Morpho-Anatomy, Cosmostigma racemosum, Asclepiadoideae

\section{Introduction}

Cosmostigma racemosum is a species belonging to the family Apocynaceae, subfamily Asclepiadoideae (Takhtajan, 2009: 522; APG III, 2009: 105-121). Backer and Bakhuizen (1963: 274) state that this species is native to Sri Lanka and India. According to Trimen (1895: 177), this species is found in India, Burma and Java. Hooker (1885: 46) states that $C$. racemosum is common in Sri Lanka but its range of distribution includes Java. This species was listed in the Appendix 1 of threatened species in Sri Lanka (Ganashan et al., 1995: 61) and in 2009 it became the protected plant because it was critically endangered (The Ministry of Forestry and Environment, Republic of Sri Lanka, 1999:105; Parlement of The Democratic Socialist Republic of Sri Lanka, 2009: 29).

Cosmostigma racemosum is also found in Nglanggeran Mountain in Pathuk, Gunung Kidul, Yogyakarta as a component of unique vegetation dominated by shrubs and lianas (Widodo, 2012: 1-15). Until now, there has been no information of the origin and the cause of its presence in Nglanggeran Mountain. This mountain is the remnant of tertiary volcano (OligoMiosen) or approximately 0.6-70 million years ago (Adhie, 2009: 1-3). Only few sources of information, such as writings, books, atlas of flora, journal as well as website regarding $C$. racemosum are available. Because there is no species data base and information of the presence of $C$. racemosum in Indonesia, it is necessary to compile data of structure characteristics of this species for authentication of its identity and systematics. Based on the results of research by Widodo (2012:1-15), it is necessary for the characterization of morphology and anatomy structure of $C$. racemosum.

In the subfamily Asclepiadoideae, Cosmostigma belongs to the tribe Marsdeniaeae. Subfamili Asclepiadoideae consists of three tribes: Marsdeniae, Ceropegieae and Asclepiadeae (Takhtajan, 2009: 529). In the classic classification, the division of tribes is based on the position of pollinia and flower. Pollinia are erect in the tribe Marsdeniae, horizontal in the tribe Gonolobinae (Ceropegieae) and pendulous in the tribe Asclepiadeae (Civeyrel 1998: 523).

The aspect of flower structure of Asclepiadoideae can be used to confirm the position of specimen in genus, subtribe, tribe and subfamily. The characteristics of flower parts, its ontogeny and development are important for tracing and confirmation of evolutionary phase and its relative position in phylogeny. Kunze (1995: 8) has made the schematic diagram of evolutionary phase of Asclepiadoideae flower based on the structure of corona, Kunze (1995: 1-24) has analyzed the structure and function of flower in Asclepiadoideae, especially the corona and gynostegium. His study revealed the morphology and evolution of corona and morphology of pollinia translator in Apocynoideae, Periplocoideae, and Asclepiadoideae.

The morphological complexity of flowers in Asclepiadoideae has confused yet, at the same time, instilled curiosity among botanists in the last two centuries (Ollerton and Liede, 2003: 107). Morphology is the most important basis for taxonomic description (Simpson, 2006: 348). Morphological characters are the outer appearance of plants. These characters provide 
characteristics which can easily be used for identification or supposition of the phylogenic relationship. Morphological characters have long been used more often than anatomical and molecular characters because the morphological characters are easier to observe and more

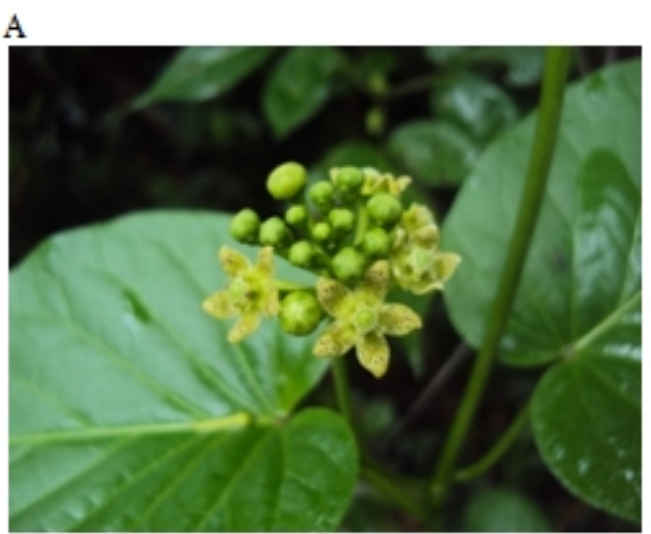

$\mathrm{C}$

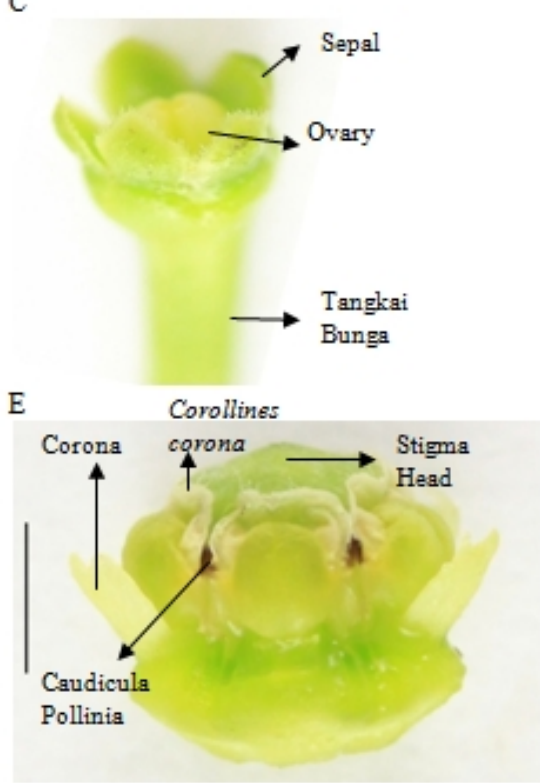

F

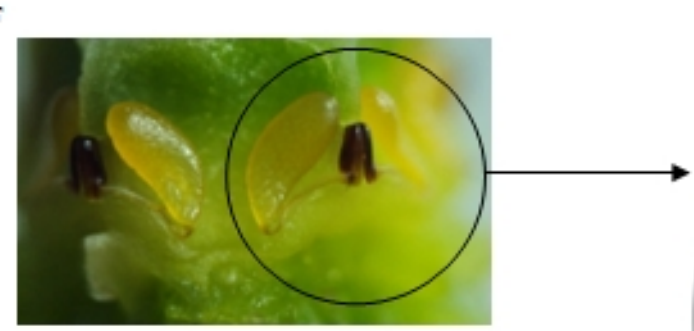

B

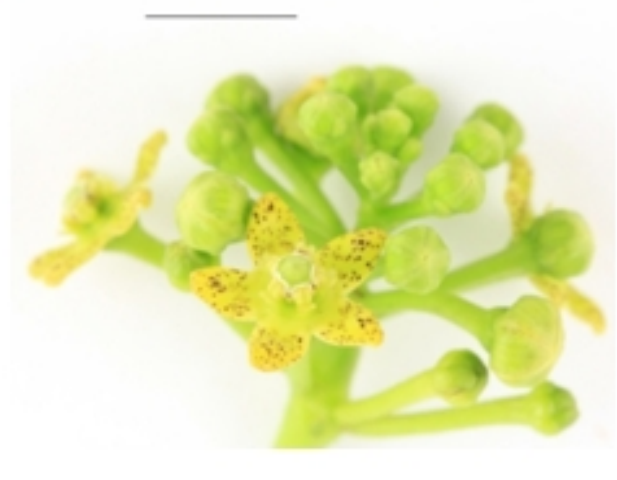

practical to use. Flower morphology is important marking characters in identification. Morphology is considered to be old fashioned but it is still the basis for the solution of taxonomical problems (Stuessy, 2009: 232).

$\mathrm{D}$

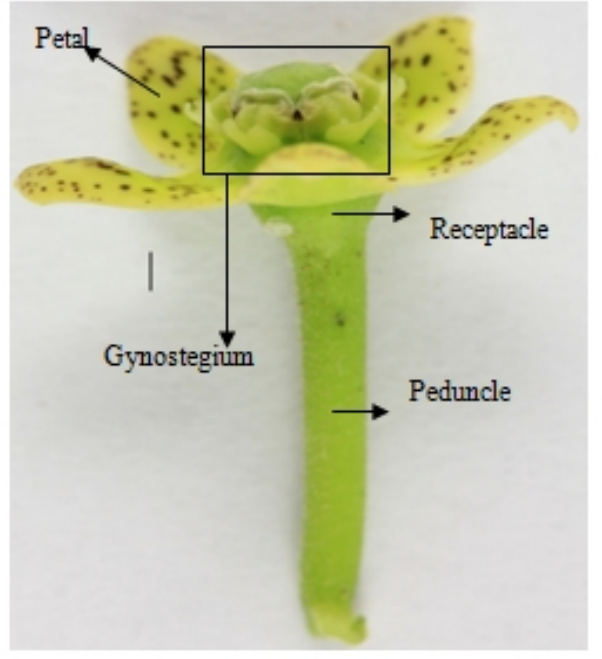

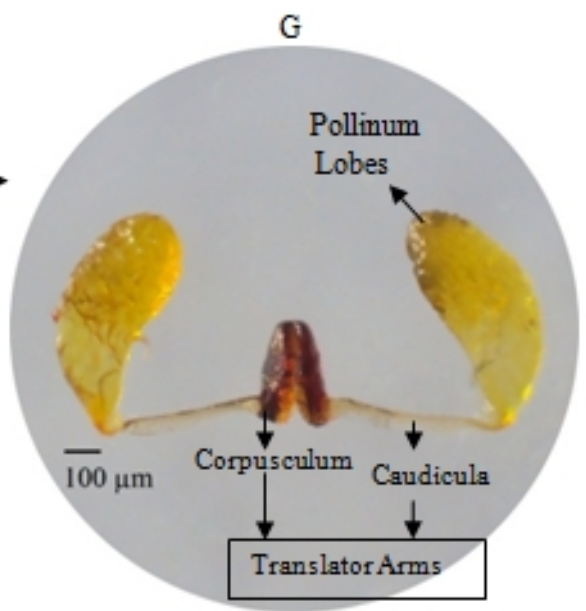

Figure 1. Flower of Cosmostigma racemosum. A, B. Inflorescence. C. Calyx and Ovary. D Individual flower. E. Gynostegium. F. Position of Pollinia at Gynestegium when the coronaria and anther wall removed. G. Pollinia unit and their parts.

The characters of plant inner structure have made significant contribution to plant systematics for more than 150 years (Judd, 2002: 55-100). Anatomical characters and inner structure of plants have been used for identification and determination of phylogenic relationship. Anatomical characters are observed using 
light microscope with simple techniques as well as electron microscope. Some important aspects of anatomical characters which have taxonomical values are flower anatomy and its development, anther development and pollen structure. Anatomical characteristics play a role in explaining the phylogenic relationship (Singh, 1999: 165).

Cervantes and Diego (2010: 1) state that description of morphological characteristics in plants is the fundamental part of botanical study and as a key to taxonomy or systematics. Currently, the studies to describe development are mostly those of gene interaction and protein control. These indicate that biology as a discipline has reached its ultimate maturity with experimental procedures and biochemistry point of view. However, all procedures based on experiments have caused the decline in descriptive aspects of morphology. Molecular data do provide information related to morphology, but the role of genes and protein in controlling morphology can only be understood if the description of morphology of plant and its parts have been understood first. De Craenne and Wanntorp (2011: 1) state that the decline of knowledge of morphology and systematics of plansts has ocured in the last decades. The studies of organisms continue to increase, but with limited knowledge of structure. This results in inaccuracy of interpretation and limitedness of research horizon. Flower morphology shows the evolutionary processes which have been occurring since 130 million years ago. Flower morphology is the best explaining component in plant systematics researches and the key for creating phylogeny which broadens the understanding of evolution and other related organs. Data of morphology are useful in clarifying molecular characters in phylogeny studies and as sources of data that help to clarify flower evolution and the underlying mechanism of flower development (De Craenne dan Wanntorp, 2011: 3).

The objective of this study was to reveal morphoanatomical structure of Cosmostigma racemosum flower. The morpho-anatomical characteristics of $C$. racemosum flower can be used for confirmation and checking at the levels of species, genus, and tribe in the existing classification hierarchy and for clarification of its phylogenic relationship in each level of taxon.

\section{Methodology}

Flowers of $C$. racemosum were collected from the Nglanggeran Mountain which lies at a latitude of S.0705" 25.5 and a longitude of E. $110^{\circ} 32$ "20.' The samples were subsequently kept in Biology Laboratory of Sunan Kalijaga State Islamic University, Yogyakarta. Samples were kept in collection bags, and some of which were put in fixative FAA (Formalin Acetic-Alcohol). Samples were collected as dry specimens, wet specimens and fresh material.

The tools for observation and collection were digital cameras Sony Nex F3, Sony Cyber-shot DSC-W180,
Canon DSLR, rulers, micrometers, calipers, small measuring tapes, collection bags, scissors, cutters, labeling paper, a GPS (Global Positioning System), tools for dried herbarium collection, flacon bottles, stereo microscopes Nikon SMZ 1500 equipped with a camera, light microscope Nikon Eclipse 50 equipped with a camera Nikon DSF1. Materials for observation and collection were distillated water, Alcohol $70 \%$, FAA (Formalin Acetic Alcohol) solution.

Tools for plant tissue dissection method consisted of: microtome Leica, oven, slide hot plate, becker glasses, measuring glasses, flacon bottles, object glasses, deck glasses, labeling paper, cutters, tweezers, spatula, and slide boxes. Materials for plant tissue dissection were: distillled water, alcohol $(30 \%, 50 \%, 70 \%, 80 \%, 96 \%)$, xylol, parafin, glycerin-albumin solution, safranin, hematoxylin, fast green, Canadian balm. The techniques and procedures for plant tissue section (slice) preparation followed Cutler et al. (2007: 170-193) and Schweingruber et al. (2011: 7).

Preparation and observation of flowers were done by observation, photographing, measurement and description of characteristics of parts of flowers, fruits and seeds. Identification of morphological characteristics was based on Cullen (2006: 1-357) and Haris and Haris (2006: 1-206). Photographing was conducted with digital cameras Sony Nex F3, Canon DSLR, and Sony Cybershot DSC-W180. Ruler or other tools were put beside the photographed materials in order to show the size of the materials. Photographing was replicated 15 times. Measurements were done using caliper, tape meter and graph paper. Observation and photographing of detailed morphology of flower's parts was done using stereo microscope Nikon SMZ 1500 equipped with a camera Nikon.

Preparation and observation of pollinia were conducted by picking gynostegium, then opening carefully the corona covering pollinia using preparation needles under stereoscopic microscope. A unit of complete pollinia was picked and isolated to get the detailed parts of pollinia and their orientation. Observation of pollinia morphology was done under a stereoscopic microscope Nikon SMZ 1500 equipped with a camera. Pollinia were photographed in their natural condition, which were attached to one side of gynostegium and their orientation was determined. Measurements taken for each unit of pollinia were the length and width of pollinia lobes, the length and width of corpusculum, the length of caudicula or translator arm. The measurement of pollinia's parts was done using objective micrometer in the stereoscopic microscope Nikon SMZ 1500 equipped with a camera and the results were then calibrated using Paint Program, Windows Picture Manager and Corel Photo Paint 12.

Slides of flower anatomy were made using parafin method with double coloring of fast green safranin. Observation of section (slice) preparation was done by observation and photographing using light microscope Nikon Eclipse 50 equipped with a camera Nikon DSF1. Observation and photographing with weak magnification 
were done for identification of shape, configuration of tissues in calyx, corolla, gynostegium, pollinia and other organs, and the configuration of an organ in the whole inflorescence. Observation and strong magnification were done for identification of structure and configuration and other details of cells which compose epidermal tissues, mesophyll, vascular tissues in calyx, corolla gynostegium, style and stamen. The measurement of cells which compose tissues was done using objective micrometer scale calibration method and the results were then analyzed using Program Paint, Windows Picture Manager and Corel Photo Paint 12.

Data analyses refered to the description and semiquantive method according to Albrechtova (2004: 13). Data in the forms of macroscopic and microscopic pictures were analyzed descriptively and comparatively. The pictures were visually presented and described or accompanied with explanation. The presentation of data in the forms of pictures, numbers, description and explanation were compared with literaures and related studies.

This research was conducted from March to July 2013 in Biology Laboratory, a part of integrated Laboratory of Islamic State University of Sunan Kalijaga, Yogyakarta.

\section{Results and Discussions}

\section{Flower morphology}

The flowers of Cosmostigma racemosum is inflorescence of racemose to corymbose type; peduncle is between the petioles of leaf pair (interpetiolaris); peduncle is brightly green; the transversal section is round, $6-8 \mathrm{~cm}$ in lenght. Pedicel is also brightly green; transversal section is round, the tip wider than the base, $1 \mathrm{~cm}$ long. The width of inflorescence is 3-4 cm (Figure 1A, B).

The individual flower of Cosmostigma racemosum is bisexual, 3-4 $\mathrm{mm}$ in height without pedicel; $9 \mathrm{~mm}$ in width when blossoming. The individual flower is shown in Figure 1C. The sepal consists of 5 parts, united at the base, $1 \mathrm{~mm}$ in length, tip obtuse; margin pubescent, brighlt green. Corrolla has 5 petals, forming into a bellshape short tube, 3-4 $\mathrm{mm}$ in length, 2-3 $\mathrm{m}$ in width, tip acuminate, surface glaborous, greenish yellow, reddishdotted. Flower has 5 corona-scales, 1 - 1,5 mm in height, tip bilobed, whitish grees. Stamen and pistil form a gynostegium (Figure 1E). 5 anthers are attached to the lateral side of stigma. Anther is protected by corollines corona. The tips of corollines corona wrap the stigma. Diameter of stigma is $2 \mathrm{~mm}$. The ovary has 2 carpels, 1 $\mathrm{mm}$ in length.

The morphological characteristics of C. racemosum flower in this study match the decription in Sivalaya Farm (2011: 1), Page (2008: 1), Backer \& Bakhuizen (1963: 274), Brandis (1906:468), Trimen, (1895:177), Hooker (1885: 46), Drury (1866: 228). The structure of corona is important for distinguishing Cosmostigma from non Cosmostigma. According to Ping-tao et al., (1995:4) the characteristics of Cosmostigma corona is that it is relatively small and thin like a membrane. The visual presentations of $C$. racemosum flowers as sketches have been available in old literatures or monographs, namely De Lessert and De Candole (1846: 84), Wight (1846: 591), Hendrik (1686: 32). The visual presentations in the forms of ancient herbarium photographs were uploaded in the web site of Herbarium Musei Parisiensis, in 2012. Description and visual presentation in this study are important and needed because the characteristics of flower have high identity value and the information of the presence of $C$. racemosum in Indonesia currently is not known except in the ancient literature of Trimen (1895: $177)$ in Flora of Ceylon, Hooker (1885: 46) in Flora of British India, and Drury (1866: 228) Flora of India. The additional description data of $C$. racemosum flower morphology contributed by this study are the position of petals (aestivatio) toward each other and the structure of corollines corona in anther. The aestivation type in $C$. racemosum is dextrostum contortus or rightward contortion. The tip and middle of the corolla lobe reduplicate or folded with margin folded outward. De Craene and Wanntorp (2011: 2) state that data of flower morphology are very good clarifying components in systematic research and the key or the main tool for developing phylogeny concept, expanding and enriching the understanding of evolution and significance of organs in evolution.

\section{Morphology of Pollinia}

Pollinia are produced by an anther. An anther consists of two theca or pollen sacs, each forming one pollinium, so there are 2 pollinia in each anther. Corona corollines form at the dorsal side of anther. An anther is fused to the lateral side of stigma forming a structural unit called gynostegium (Figure 1E). Corpusculum is shiny brown located between anthers. Corpusculum is connected by caudicule to two pollinia lobes from two different anthers, namely one on its right and the other on its left side (Figure 1F). Pollinia lobe is erect, obovate, golden yellow (Figures 1F, G), 550-600 $\mathrm{m} \mu$ in length, 200-250 $\mathrm{m \mu}$ in width. Caudicule or translator leg is clyndrical, 500-600 $\mathrm{m} \mu$ in length, without membrane. Corspusculum is ovate, cleft in ventral side, $250 \mathrm{~m} \mu$ in length, $150-200 \mathrm{~m} \mu$ in width, shiny blackish brown.

The color and structure of corpusculum of $C$. racemosum ensure its position as a member of the subfamily Asclepiadoideae. The characteristics of pollinia lobe of $C$. racemosum, namely erect, ovate, relatively long caudicule without membrane, ensure its position as a member of the tribe Marsdenieae. Shape, size, location, orientation, and location of line, are important criteria of pollinia morphology (Sreenath et al., 2012:45-53; Sinha dan Mondal, 2011:7981-7986; Rahman, 1990: 83), which play an important role in identification of tribe and genus. The results of this study confirm the classification Takhtajan (2009: 522) which put Cosmostigma racemosum in the tribe Marsdenieae. 


\section{Anatomy of floral development}

Longitunal section of inflorescence in Figure 2 shows that C. racemosum inflorescence is of racemose type (inflorescentia racemosa). The development of inflorescence unit starts from the edge or bottom of the inflorescence. There is a small bractea on each base of inflorescence unit. Trichomate are on the bractea and leaf surface. Figure $2 \mathrm{~B}$ shows the early development of inflorescence unit. The characterics of early inflorescence development indicate that sepals occupy the main proportion of flower; colleter gland in calyx base is clearly visible. Stigma also occupies a large proportion of flower. Stamens are cleary visible, consisting of filaments and anther. The bases of filaments are attached to the base of corolla. The wall of pollen sac (theca) begins to differentiate simultaneously with the formation of pollen. The next step is the enlargement of flower (Figure 2D), indicating the following characteristics: elongation of corolla base, the expansion of stigma to the periphery so that it press and lift the anther. The anther's position is precisely on the lateral side of stigma. The development of ovary is clear; the wall of anther and theca (pollen sac) which contain pollinia are clearly visible. The maturation of pollinia is happening. The wall of anther clearly shows the layers of tapetum, middle layers and endotesium.

The stage of blossoming is shown in Figures 2D, E with the following characteristics: the corolla dominates the proportion of the flower; the stigma is lfted by the uniting tissues of corolla base, calyx and stamen. Pollinia and their components (tapetum, middle layer, endotesium) adhere to upper lateral side of stigma. The remaining structure of anther sticks to stigma and becomes corollines corona which protects pollinia; the stigma is lifted away from ovary.

The presence of bractea at the primodial stage of infloresence development confirms the position of $C$. racemosum as a member of the subfamily Asclepiadoideae which ontogenically has bractea like inflorescence in Apocynoideae. The data of the presence of braktea during primordial phase of inflorescence development also rectify the statement of Hooker (1885: 42) that the bractea in Cosmostigma racemosum is zero (0). But the same data may also confirm the statement of Hooker if what he means by $(0)$ is that ontogenically C.racemosum has bractea.

\section{A}

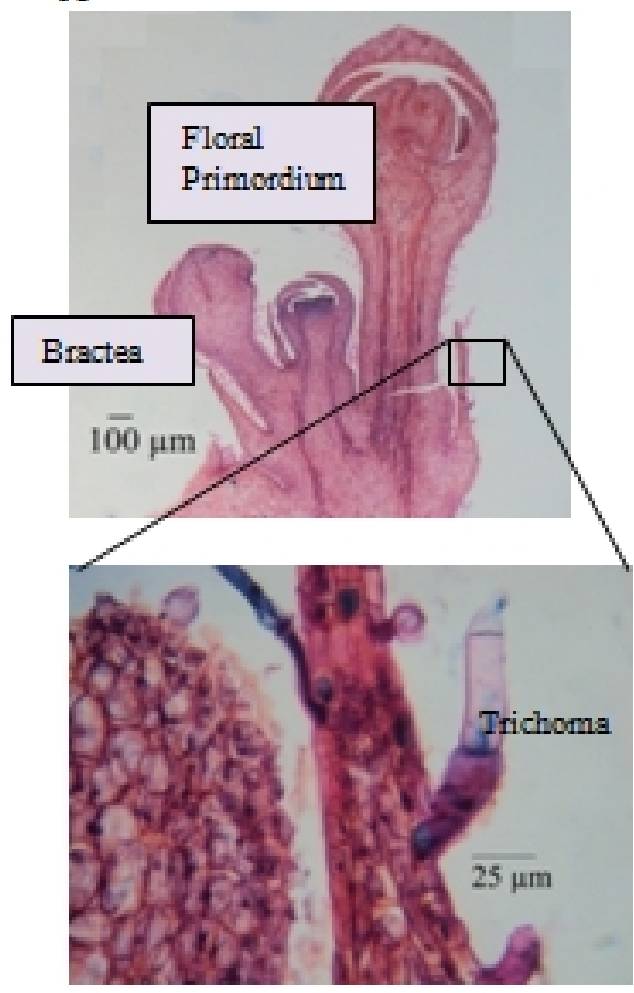

B

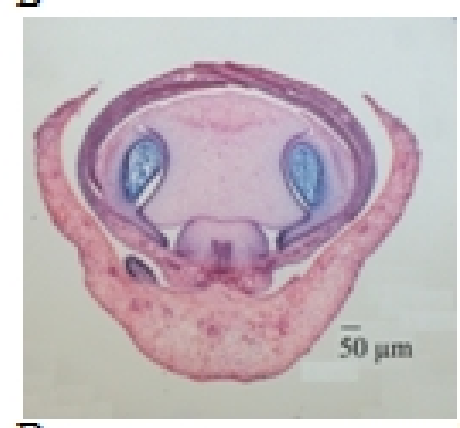

D

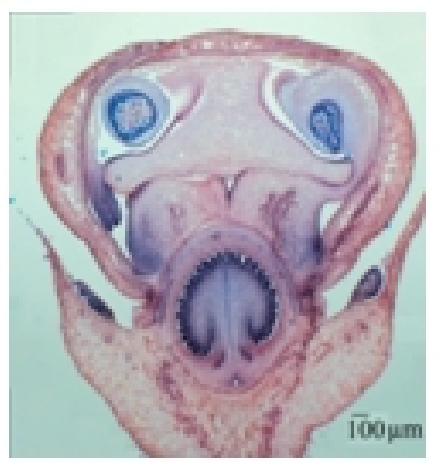

$\mathrm{C}$

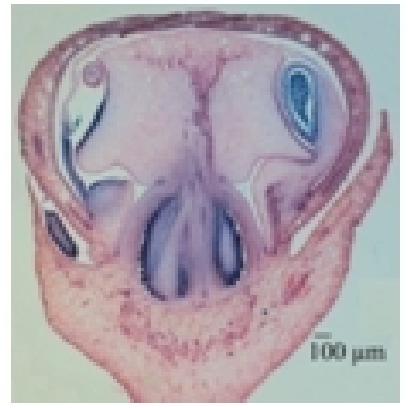

E

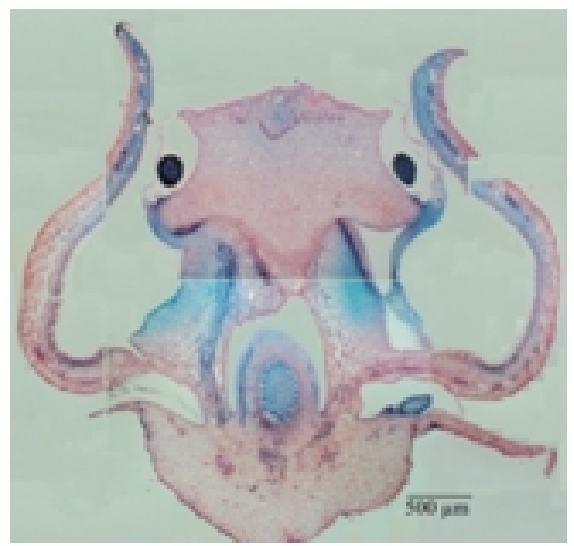

Figure 2. Longitunal section of Cosmostigma racemosum flower. A. Section of young inflorescence Insert: Bractea and trichoma. B, C, D, E. Flower development.

Data of flower development anatomy clarify the proccess of gynostegium structure formation (the fusion of stigma and anther) in C. racemosum. The early development shows that the structure of stamen is not united with stigma, so the fusion of stigma and anther is difficult to explain. Data of flower development can complement, clarify or support the concept of flower phylogeny of Asclepiadoideae presented by Kunze
(1995:1-24). The early stage of flower structure of Asclepiadoideae is similar to that of Apocynoideae so that phylogenically Apocynoideae precedes Asclepiadoideae. Data of floral development also show that gynostegium is formed and then lifted due to the elongation of staminal tube and ovary. Data of flower development show the development of the wall of anther and theca (pollen sac) and the ontogeny of pollinia. 


\section{Anatomy of longitudinal section of receptacle, calyx, corolla, stamen and pistil}

The longitudinal section of blossoming inflorescence of C. racemosum shows the flower parts, namely receptacle, calyx, corolla and gynostegium (the fusion of stamen and pistil). The parts and the tissue structures are shown in Figure 3.

Figures 3B-C show tissues of receptacle and calyx. Receptacle consists of large cells and its outer side is covered by flat epidermal cells with stomata among which. The tissues of calyx consist of upper (adaxial) epidermis, mesophyll, and lower (abaxial) epidermis. The upper epidermis in calyx consists of a layer of flat elongated cells $(15-25 \mu \mathrm{m})$. The mesophyll of calyx is composed of rounded cells and it has small vascular tissues. The abaxial epidermis consists of cuboid cells $(20 \times 20 \mu \mathrm{m})$ and stomata among which. Colleter gland is found at the abaxial surface of base of calyx (Figure 3D). The border between calyx and receptacle tissues is not clear. The tissues in calyx are more differentiated than those in receptacle. The mesophyll cells in tissues of receptacle are larger than those in calyx tissues.

\section{A. Longitudinal Section of Flower}
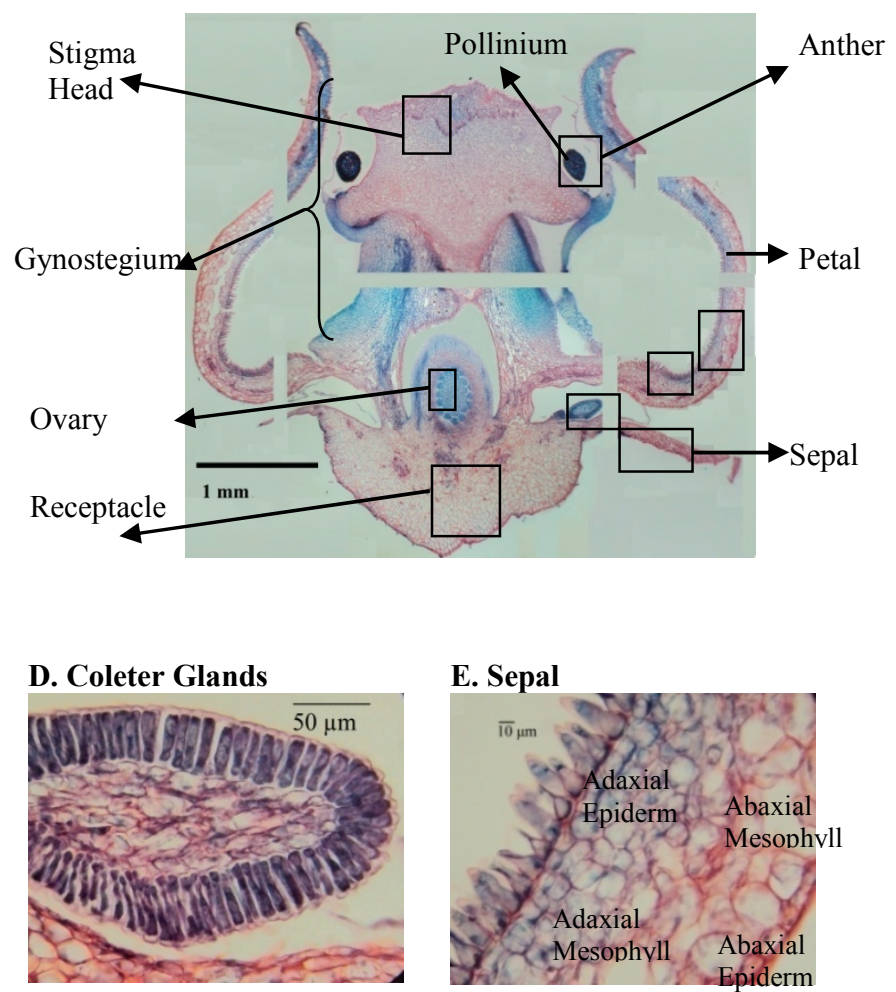

\section{E. Sepal}

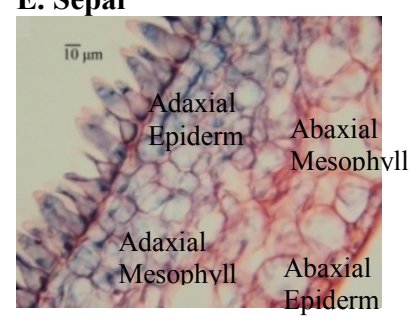

\section{B. Receptacle}
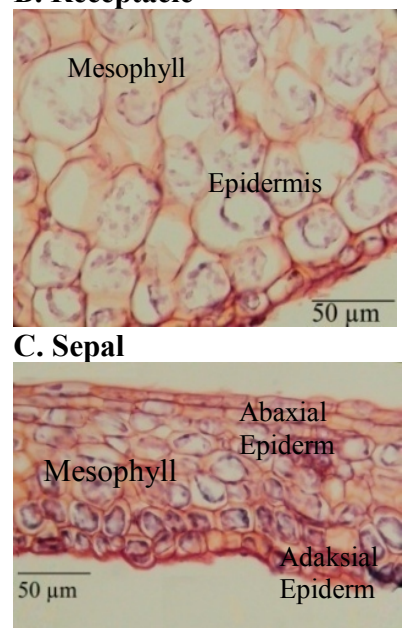

F. Basal of Petal

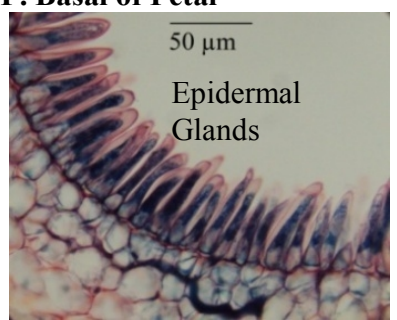

J. Ovary
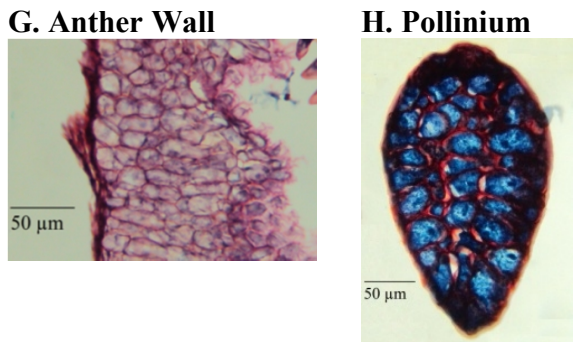

I. Stigma Head

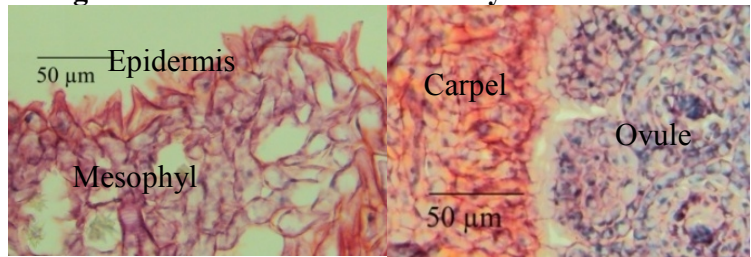

Figure 3. Tissues in longitudinal section of Cosmortigma racemosum flower.

Characteristics of calyx of $C$. racemosum are: the presence of colleter gland at the base of the connection of two callyces, so there are five colleter glands. The colleter gland produces sticky slime or resin, insoluble in water. The function of this gland is to protect dormant buds and meristem development, leaf buds, and young stipules (Evert, 2006: 459). The colleter gland in the callyx of $C$. racemosum flower is of the general standard type, namely long head and short stalk. The head is covered with epidermal cells that look like palisade. The colleter type of $C$. racemosum belongs to the type of the family Apocynaceae. The presence of colleter in the callyx of Apocynoideae was reported by Martins et al. (2013: 21) in Secondatia densiflora, whereas the presence of colleter in the calyx of Asclepiadoideae was reported by Silva et al. (2008: 924) in Oxypetalum. The presence of colleter gland or glandula emergentia in the base of calyx of the tribe Marsdenieae of Asclepiadoideae was 
found by Valente dan Costa (2005: 53) in Marsdenia loniceroides. The presence of colleter gland in the calyx of Cosmostigma racemosum shows that the petals and sexual apparatus of flower have been and prevented from drought since they are still buds.

Figure $3 \mathrm{E}$ shows the arrangement of corolla tissues. The corolla is composed of several tissues: adxial (upper) epidermis, mesophyll (the densely-packed and spongy mesophylls) and abaxial (lower) epidermis. Adaxial epidermal tissues at the tip of corolla consist of short papilla cells while abaxial epidermis consists of a layer of flat cells with stomata. The papilla cells of adaxial epidermis get more elongated in the middle and base of corolla. The structure of papilla cells at the adaxial epidermis at the base of corolla is of glandular type (Figure 3F). The structure of papilarry epidermis like palisade at the adaxial surface of corolla base of $C$. racemosum indicate is function as nectariferous tissue. In this tissue, epidermal cells function as secretory gland. The characteristic of nectar epidermis is the presence of trichomate cells or the elongated cells like palisade (Evert, 2006: 453).
A

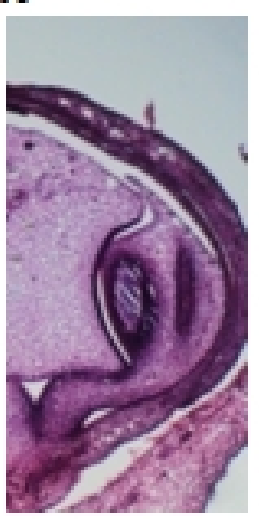

B

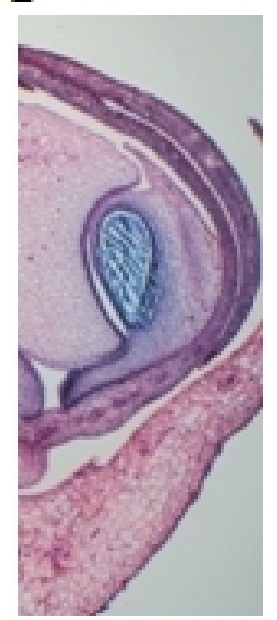

$\mathrm{C}$

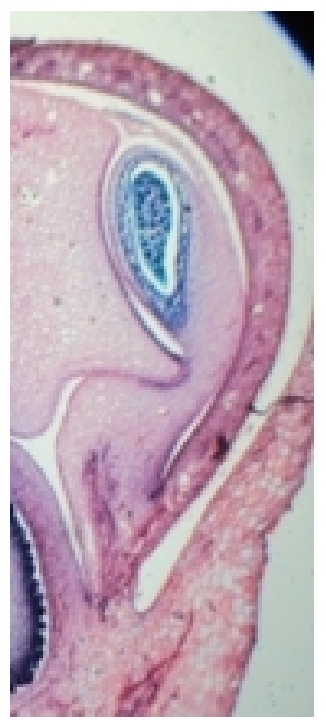

D

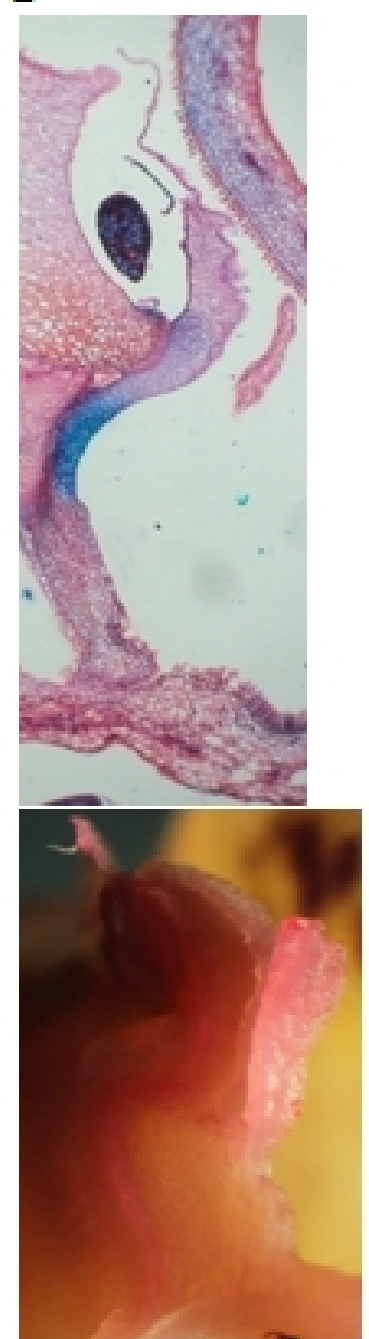

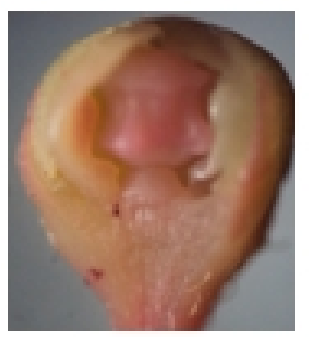

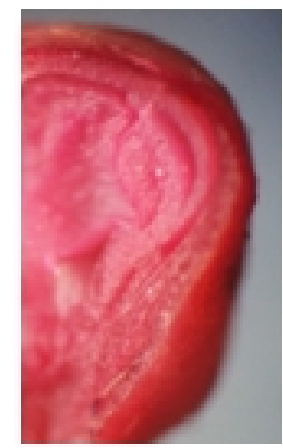

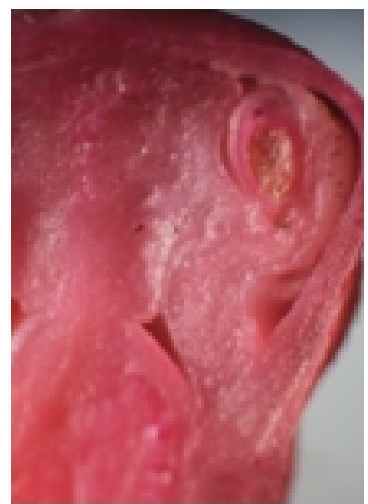


The mesophyll tissues of $C$. racemosum flower are differentiated based on cell size and density. The difference between the the dense and spongy tissues can be observed by safranin-fast green double coloration. The dense mesophyll tissues consist of densely-packed round cells with limited intercellular spaces, and the cells contain chloroplast. The presence of cholorplast in densely packed mesophyll indicates that the petals of $C$. racemosum still have photosynthetic function. The spongy mesophyll tissues consist of long-rounded cells larger than the cells in densely packed mesophyll tissues. There are more intercellular spaces and vascular tissues at the border with densely packed mesophyll tissues.

Figure $3 \mathrm{G}$ shows the arrangement of tissues of anther wall. Figure $3 \mathrm{H}$ shows the mature pollinia in the broken anther sac. The base of anther sticks to the lateral side of stigma. Anther and pollinia are at the depression of lateral side of stigma. The upper tip of anther wall is additional corona or corollines corona. The additional corona is composed of thin layer of outer and inner epidermis, the reduced mesophyll containing druse crystal. Parts of the whole stamen can be seen in Figure 3A. The lower part of an anther is a filament which is the extension of stamina tube, which in turn is the extension of corolla base which wrap the ovary. The term staminal tube is adopted from tubo estaminal (Silva et al., 2008: 929; Valente dan Costa, 2005: 53). The cells at the periphery of staminal tube look larger than those in the middle. The staminal tube wall facing the base of filament shows epidermal gland. The longitudinal section crossing the middle of corona shows that the tissues of stamen base and staminal tube are united (indistinguisble), while the tissues of corona base tend to separate from staminal tube. These data show the ontogenical difference between the two tissues.

The tissues of anther consist of upper epidermis, mesophyll, and inner epidermis. The upper epidermis is composed of densely-packed longitudinally elongated flat cells. The mesophyll consists of densely packed round cells. The inner epidermis consists of papilla cells larger than those in mesophyll. The tissues of filament are composed of outer epidermis, mesophyll and inner epidermis. The outer epidermis consists of densely packed small flat cells. The mesophyll is composed of densely-packed, small rounded cells. The inner epidermis is composed of glandular cells which can be sheded. The inner side of filament seems to be asscociated with the base of stigma and the tip of stamina tube forming a secretion-laden sac.

The arrangement of stigma is shown in Figure 3I while the arrangement of ovary is shown in Figure 4J. The stigma consists of epidermal tissues and mesophyll tissues. The outer epidermis of stigma is composed of short papilla-shaped cells like those in adaxial epidermis of corolla. The shape of mesophyll cells look like spongy tissues but with limited intercellular spaces. Many druse crystalls are found in the mesophyll tissues of stigma. In the lower middle part of mesophyll of stigma there are xylem vessels with thickened ring. The part of stigma which sticks to anther is composed of glandular cells producing secretion. Ovary consists of wall and sacs containing many ovules.

\section{Anatomy of stamen and pollinia development}

Figures 4A-D show the development of stamen of Cosmostigma racemosum. Transversal section of young flower (Figure 4A) shows that the base of stamen is at the junction between ovary and corolla. Anther and filament are separate parts from stigma so that gynostegium has not been formed. Theca or pollen sacs have been formed but the wall differentiation has not been complete. Corollines corona at the tip of anther is still at the early stage of development. Orderly layers of pollen as the precursors of pollinia are seen. Staminal tube has not been formed in this immature flower.

The maturation process of stamen is shown in Figures 4C-D. Anther is lifted at the same time with the elongation of filament. The base of filament is also lifted and forms staminal tube. The base of anther sticks to the lower lateral side of stigma, so the gynostegium has been formed. The wall of theca (pollen sacs) shows the layers of tissues of tapetum, middle layer and endotesium. Pollinia have been formed and there is space between pollinia and the anther wall. Corollines corona has been elongated.

The mature stamen and pollinia are shown in Figure 4D. The tissues of theca wall have been broken but the tissues of anther and corolines corona are still present. The staminal tube has been maximally elongated. The stamina tube function as the supporting structure for stigma and its tip function as the base of filament. Gynostegium structure has been completely formed at the blossoming flower. Pollen in mature pollinia emits shiny blue fluorenscent light while the wall of sporopollenin emits orange fluorescent light.

Data of stamen development clarify the origin of staminal tube and the formation of gynostegium in $C$. racemosum flower wich can be traced ontogenically. Filament structure in gynostegium is maintained until mature stage. This indicates that $C$. racemosum belongs to a group closely related to Apocynoideae or the lower group of the sub-family Asclepiadoideae. The lower groups of the sub-famili Asclepiadoideae are the tribes Fockeeae and Marsdenieae.

Polinia of C. racemosum are the aggregation of pollen grains. Polinia of Asclepiadaceae (Asclepiadoideae) are wrapped by sporopollenin. The sporopollenin wall extends entering each group of pollen grains so that all pollen grains are not united. The outer wall of sporopollenin is called pollinial wall, while the extension of wall into the units of pollen grain group is called extension of pollinian wall (Srideevi et al., 1990: 324). In general sporopollenin wall is soluble in hot 2aminoethanol solution. Srideevi et al. (1990: 324) states that young pollinial wall in Tylophora (Asclepiadaceae) is soluble in hot 2-aminoethanol solution but the wall of mature pollinia is not. Pollen grains in intact pollen can be observed using light without coloring because they emit fluorescent light or autofluorescence. 
(Pacini dan Franchi, 1999: 303). The emission of fluorescence indicates the maturation stage of pollnia.

\section{Anatomy of transversal section of flower}

Transversal sections of Cosmostigma racemosum flower from the top to the base of stigma were observed at 8 points (Figure 5).

The first point of section crossing the the upper stigma in Figure 5A shows the tissues of corolla, anther and stigma. The tissues of corolla consist of abaxial epidermis, mesophyll cells at the abaxial side, mesophyll cells at adaxial side and adaxial epidermis (Figure 5E). Epidermal cells and mesophyll cells at abaxial side are larger than those in mesophyll cells at adaxial side. Vascular bunddels are located between abaxial and adaxial mesophylls. Each petal shows three vascular bundles. Stomata are located in outer abaxial epidermis. The tissues of stigma are composed of ground tissues with one vascular bundle and two pollen sacs (Figures 5G, H). Pollen sac is round and and each sac has one pollinium. The tissues of stigma consist of extensive mesophyll tissues, in the middle of which are circles of vascular bundles (Figure I). The epidermis or the outer layer is composed of densely packed tube-shaped epidermal cells, some of which are glandular (Figure 5J).

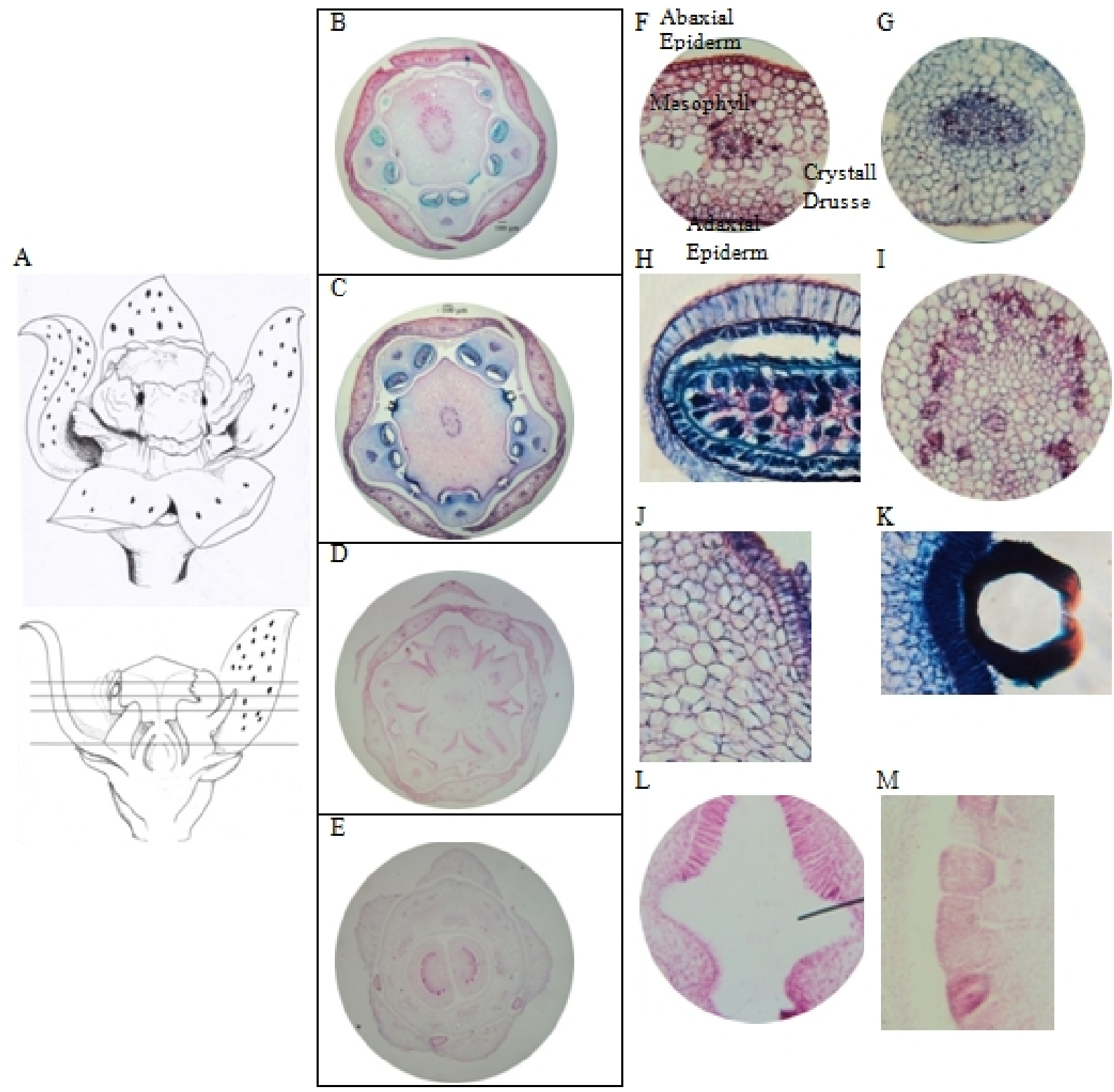

Figure 5. The transversal sections of tissues of Cosmostigma racemosum Flower. A. Sketches and point of transversal section, B-E. Transversal section, F. Corolla tissues, G. Vacular bundle in anther, H. Anther sac containing pollinia, J. Tissues of stigma, K. Section of corpuskullum of pollinia, L. Stigmatic sac, M. Ovule.

The second point of section crossed the middle of pollinia lobe. In this section, the pollen sacs look flat, oval to round-shaped. The tissues of vascular bundles at the pistil show two sliced circles. At the periphery of the stigma there is an attachment of transversal section of pollinia corpusculum as shown in Figure $5 \mathrm{~K}$. There are two shapes of epidermal cells at the lateral side of stigma, namely: a) dense smaller columnar shape and b) secretory 
large, columnar shape. The smaller epidermal cells are at the lateral side of stigma facing anther, while the large, secretory cells seem to be the components of corpusculum and caudicule.

The third point of section crossing the lower part of stigma base shows the characteristics of the edge of anther which are extending and folded outward. The junction of two edges of anther base forms a stigmatic chamber as shown in Figure 5L. The stigmatic chamber is located under corpusculum. The transversal section of style look rounded with two circles of vascular bundles tightly close to each other. The tissues of mesophyll are rounded-ovate and densely packed. Epidermis is composed of densely packed tube-shaped cells. In this section style is surrounded by five stigmatic chambers. The transversal section of corolla has 8-9 vascular bundles.

The fourth point of section crossed the ovary. This section shows that the transversal section of corolla tissues has 3 (x5) vascular bundles. The transversal section of corolla is attached to the base of staminal tube. The staminal tube has 1 (x5) kidney-shaped vascular bundle. This section shows two ovaries, each having ovules. Each carpel wall has 8-12 vascular bundles, one of which is larger than the others. Each ovary has 8-14 rows of ovules. The transversal section of the base of staminal tube circles the ovules. What remains of the stigmatic chamber is a narrow curve as the border between the remains of anther base. Five tissues of transversal section of calyx are outside of corolla tube circle. At the junction among calyx there is a colleter gland.

Data of structure of flower organ and tissues of Cosmostigma racemosum in transversal section strengthen and clarify the data obtained from longitudinal section. The transversal section through stigma shows: lay out and orientation of petals from one another, arrangement of corolla tissues at the tip or distal, number of layers of anther structure, location of anther, arrangement of anther tissues, number of theca or anther sacs, structure of theca, structure of anther wall, location and position of stigma, structure of stigma, arrangement of stigma tissues.

The structure of stigmatic chamber of Cosmostigma racemosum as a member of the tribe Marsdenieae is relatively similar to that of Marsdenia loniceroides presented in the result of research by Valente et al. (2005: 55). The stigmatic structure and its extension vertically downward under staminal tube widen the pollination reach. Staminal tube is a set of tissues, forming rings made into 5 main lobes. Each has three sub-lobes (a large one in the middle accompanied by two small ones). The junction of main lobes is a downward longitudinal vessel and an extension of stigmatic chamber. Epidermal cells at the vessel between the main lobes or small lobes are secretory or glandular. The arrangement of staminal tube is essentially the same as that of vascular bundle which extends laterally. Stigamaric chamber is directly connected to the tip of ovary with no staminal tube in between.
The transversal section crossing ovary shows two seperate ovaries or apocarps, each having half-rounded shape transversally. The two ovaries are not the same in sizes; one is smaller than the other. Each ovary has many ovules. Analyses of observation and confirmation of carpel types according to Esau in Suradinata (1998: 235) show that each visible ovary consists of one carpel arranged in conduplicate involution with placenta of parietal ovules. Each ovary has one ovary chamber. Tissues of carpel is composed of three $(1+2)$ large vascular bundles and $12(6+6)$ larger ones. Colleter gland is found in the edge of intersection among sepals,

The structure of pistil with the ring of vascular bundle inside shows that stigma has two vascular bundles which have been fused. Toward the base of stigma, the vascular bundle get separated from each other and become two sliced rings. The fact that pistil has two apocarps seems to be contradicted with the evolutional trend of style and ovary. Apocarp is supposed to have its own style. Morphology of female sexual organ and its terminology are still disputable (Hidayat, 1995: 226). The presence of two apocarps but only one stigma in C. racemosum and Asclepiadoieae in general confirm that statement. A phenomenon that a flower has apocarps but the stigmas are united is explained by Kunze (1995: 5) as post genital fusion. Study of Kunze (2005: 347) also found this post genital fusion in the formation of stamina corona and corollines corona.

\section{Conclusion and Suggestion}

Morphological characteristics of Cosmostigma racemosum flower in this study are in accordance with the existing description in literatures. New data are found regarding specific structure of anatomy or flower parts and tissues, developments of flower, stamen, anther wall, anther chamber and pollinia, formation of pollinia, ontogeny of pollinia corpusculum, position of stigma, and structures of staminal tube, stigmatic chamber and ovary. Characteristics of pollinia are specific morphological characters of anther for species identification. New data of flower structure anatomy confirm the position of $C$. racemosum in the tribe Marsdenieae. Data of flower development anatomy especially stamen development of C. racemosum shows its ontogeny and clarify in the tribe Marsdenieae, subfamily Asclepiadoideae as well as filogeny of the tribe Mardenieae in the subfamili Asclepiadaceae.

Species authentification of $C$. racemosum and other members of Asclepiadoideae can be done by matching data of pollinia, structure of morpho-anatomy of flower. All data of shape and qualitative characters of structure are primary characteristics for cross checking and authentication. Data of morpho-anatomy of $C$. racemosum flower can be used to complement the evolutionary analyses of Asclepiadoideae, tribe Marsdenieaae currently in trend. 


\section{Acknowledgment}

The author is grateful to all parties who have helped him to conduct this study, especially the Directorate General of Higher Education, The Ministry of Religion of the Republic of Indonesia which funded this study.

\section{References}

Angiosperm Phylogeny Group III. (Birgitta Bremer, Kåre Bremer,Mark W. Chase, Michael F. Fay, James L. Reveal, Douglas E. Soltis, Pamela S. Soltis and Peter F.Stevens). 2009. An Update of The Angiosperm Phylogeny Group Classification for The Orders and Families of Flowering Plants: APG III. Botanical Journal of the Linnean Society.161: 105121.

Adhie, B. 2009. Selintas Tentang Kondisi Geologi Gunung Api purba Nglanggeran Desa Nglanggeran, Kecamatan Patuk, Kabupaten Gunungkidul. Leaflet.Yogyakarta: Disparbud Gunungkidul.

Albrechtova, J. 2004. Plant Anatomy in Environtmental Studies. Prague: Charles University in Prague

Ayers, G. S. 2006. The Asclepiadaceae-The Milkweed Family. American Bee Journal. 1051-1054.

Backer, C.A.\& Bakhuizen. 1963. Flora of Jawa (Spermatophytes Only). Vol I, II, III. Groningen: N.V.P.Noordhoff.

Brandis, D. 1906. Indian Trees: An Account of Treea,Shrubs, Woody Climber, Bamboos and palms Indigenous or Commonly Cultivated in The British Indian Empire. London: Archibald Constable and Co.

Cervantes, E., De Diego, J. G. 2010. Moorphological Description of Plants: New Perspectives in Development and Evolution. International Journal of Plant Developmental Biology, 4 (1): 68-71.

Civeyrel, L. Le Thomas, A., Ferguson, K., Chases, M. W. 1998. Critical Reexamination of Palynological Characters Used to Delimit Asclepiadaceae in Comparison to the Molecular Phylogeny Obtained from Plastid matK Sequences. Molecular Phylogenetics and Evolution, 9 (3): 517-527.

Convention on International Trade in Endangered Species of Wild Fauna and Flora. 2011. Global Strategy for Plant Concervation of The Convention on Biological Diversity (Decesion 15. 19). Geneva: Nineteenth meeting of the Plants Committee.

Cullen, J. 2006. Practical Plant Identification.Cambridge: Cambridge University Press.

Cutler, D. F., Botha, T.and Stevenson, D. W. 2007. Plant Anatomy An Applied Approach. Victoria: Blackwell Publishing.

De Craene, L. P. R., and Wanntorp, L. 2011. Introduction: Establishing The State of The Art The Role of Morphology in Plant Systematics. Dalam De Craene, L. P. R., and Wanntorp, L (Eds.), Flowers on The Tree of Life (hlm. 1-7). New York: Cambridge University Press.

De Lessert, B. 1802. Icones Selectae Plantarum Quas in Systemate Universali: ex Herbariis Parisiensibus, Praesertim ex Lessertiano. Parisiis: Apud Fortin Masson et Sociorum.

De Lessert, de Candole, A. P. 1848. Icon Selectae Plantarum Vol. 5.

Drury, H. 1866. Handbookof The Indian Flora. Great Brittain: Trabancores Sirear Press.

Dwari, S., Mondal,A. K.2011. Systematic Studies (Morphology, Anatomy and Palynology) of Economically Viable Grass Brachiaria mutica (Forsskil) Stapf in Eastern India. African Journal of Plant Science, 5 (5): 296-304.

Endress,M. 2004. Apocynaceae: Brown and now. Telopea 10(2): 526

Evert, R. F. 2006. Esau's Plant Anatomy. New Jersey: John Willey $\&$ Sons.
Ganashan, P., Balendira, S., Dassanayake, M. D. 1996. Country Report to The FAO International Technical Conference of Plant Genetic Resources. Paradeniya: April 1995

Gujarat Ecology Commission. 1996. Biological Diversity of Gujarat. Baroda: University of Baroda Press.

Harborne, A. J. 1998. Phytochemical Methods. London: Chapman and Hall.

Haris, J. G. and Haris, M. W. 2006. Plant Identification Terminology, An Illustrated Glossary. Utah: Spring Lake Publishing.

Hegnaijer, R. 1967. Chemical Characters in Plant Taxonomy: Some Possibilities and Limitations. Leiden-Netherlands: Laboratoriuin voor Experimentele Plantensystematiek.

Hendrik, van R. 1686. Hortus Indicus Malabaricus Vol. 7

Herbarium Museum National d' Histoire Naturelle Paris. 2012. Cosmostigma racemosum. http://colb.mnhn.fr.

Hidayat, E. B., 1995. Anatomi Tumbuhan Berbiji. Bandung: Penerbit ITB.

Hill, D., Fasham, M., Tucker, G., Shewry, M., Shaw, P. (Eds.).2005. Handbook of BiodiversityMethods Survey, Evaluation and Monitoring. Cambridge: Cambridge University Press.

Hillig, K. W and Mahlberg, P. G. 2004. A Chemotaxonomic Analysis of Cannabinoid Variation in Cannabis. American Journal of Botany. 91 (6): 966-975.

Hooker, J. D. 1885. Flora of British India. London: Reeve and Co. Indhumathi, D., Kalvimoorthi. 2010. Parmacognostic Preliminary Phytochemical and Antimicrobial Activity on the Whole Plant of Sarcostemma secomone (L) Bennet. International Journal of Pharmaceutical Science Review adn Research, 1 (2): 49-55.

International Plant Name Index (IPNI).2012. Cosmostigma.http://www.plantsystematics.org, accessed on 23 February 2012

John, S. B. Jr. and Luchsinger. 1986. Plant Systematics. New York: McGraw-Hill.

Judd. 2002. Taxonomic Evidence: Structure and Biochemical Character. Plant Systematic: A Phylogenetic Approach. Sunderland, MA: Sinaeur Ass. Inc.

Kawale, P. 2012. Green Milkweed Creeper. Flower of India. (http:/www.flowersofindia.in). accessed on 12 December 2011.

Kidyoo, M. 2012. Hoya mirabilis Kidyoo, a New Species of Hoya from Western Thailand (Asclepiadaceae).Tropical Natural History 12(1): 21-28.

Knowles, B. 2008. Systematics and Taxonomy Response to the House of Lord Science and Technology Committee. Bioscience Federation, United Kingdom, 4 February 2008.

Kunze, H. 1995. Structure and function of the flower in Asclepiadaceae. Phyton. 35 (1): 1-24.

Kunze, H. 2005. Morphology and evolution of the corolla and corona in the Apocynaceae s. 1. Bot. Jahrb. Syst. 126: 347-383.

Leggett, R and Kirchoff, B. K. 2011. Image Use in Field Guides and Identification Keys: Review and Recommendations. AoB PLANTS 2011:1-37.

Lens, F., Endress, M. E., Bass, P., Jensen, S. and Smets, E. 2009. Vessel Grouping Pattern in Subfamilies Apocynoideae and Periplocoideae Confirm Phylogenetic Value of Wood Structure within Apocynaceae. American Journal of Botany. 96 (12): 2168-2183.

Madhurima, Anshari, S. H., Alam, P., Ahmad, S., Akhtar, S. 2009. Pharmacognostic and Phytochemical Analyze of Gymnema sylvestre (Br) Leaves. Journal of Herbal Medicine and Toxicology, 3 (1): $73-80$.

Martins, F. M., Mascarenhas, A. A. S., Macedo, T. P., Neto, C. I. L. 2013. Estruturas Secretoras em Orgãos Vegetativos e Florais de Secondatia densiflora. Rev. Bras. Pl. Med., Botucatu, V (1): $13-24$.

Ministry of Forestry and Environment. 1999. Biodiversity Conservation in Sri Lanka: A Framework for Action. Battaramulla: Ministry of Forestry and Environment Sri Lanka. 
Missouri Botanical Garden. 2010. Illustration of Cosmostigma racemosum Wight.

Muthumperumal, C., Parthasarathy, N. 2009. Angiosperms, Climbing Plants in Tropical Forests of Southern Eastern Ghats, Tamil Nadu, India. Check List 5(1): 092-111, 2009

Nag, A., Kshetrapal, S. 1990. Vessel in Some Asclepiadaceae. Ancient Science of Life. 19 (3): 168-173.

Nadkarni. A. K. 1996. Indian Materia Medica. Bombay: Popular Prakasham.

Ollerton, J. and Liede, S. 2003. Corona Structure in Cynanchum: Linking Morphology to Function. Ecotropica, 9: 107-112.

Pacini, E., Franchi, G. G. 1999. Pollen Grains Sporoderm and Type Dispersal Unit. Acta Societatis Botanicorum Poloniae, 68 (4): 299-305.

Page, N. 2008. Green Milkweed Creeper. http://crdd.osdd.net/indipedia/index.php/Green_Milkweed_Cr eeper. accessed on 12 December 2011.

Parliament of The Democratic Socialist Republic of Sri Lanka. 2009. Fauna and Flora Protection (Amendment) Act, No. 22 2009. Colombo: The Government Publications Bureau.

Patil, V. S., Rajput, K. S. 2008. Structure and Development of Inter and Intraxylary Phloem in Leptadenia reticulata (Asclepiadaceae). Polish Botanical Journal, 53(1): 5-13.

Ping-tao, L., Gilbert, M. G., Steven, W. D. 1995. Asclepiadaceae. Flora of China. 16: 189-270.

Poornima, N., Umarajan, K. M., Babu, K. 2009. Studies on Anatomical and Phytochemical Analysis of Oxystelma esculentum. Botany Research International, 2 (4): 239-243.

Rahman, M. A. 1990. Pollinia of Some Tropical Asian Asclepiadaceae. Dalam P. Baas et al. (Eds.), The Plants Diversity of Malesia (83-92). Kluwer Academic Publisher.

Rapini, A. 2012. Taxonomy "Under Contruction": Advances in The Systematic of Apocynaceae, with Emphasis on The Brazilian Asclepiadoideae. Rodriguesia, 63 (1): 075-088.

Rapini, A., Berg, C., Schumann, S. L. 2007. Diversification of Asclepiadoideae (Apocynaceae) in The New World. Ann. Missouri Bot. Gard., 94: 407-422.

Sambamurty, A. V. S. S. 2005. Taxonomy of Angiospermae. New Delhi: I K International Pvt Ltd.

Saneja, A., Sharma, C., Aneja, K. R., Pahwa, R. 2010. Gymnema sylvestre (Gumar): A Review. De Pharmacia Lettre, 2 (1): 275 284.

Saralla, R. P., Narendran, R., Umarani, V., Sridharan, K., Brinda, P. 2012. Pharmacognostic Standards for Diagnosis of Pentatropis capensis (Asclepiadaceae) a Plant Drug Used in Indian System of Medicine. International Journal of Pharmacy and Pharmaceutical Sciences, 4 (2): 91-97.

Schweingruber, F. H., Börner, A., Schulze, E.D. 2011. Atlas of Stem Anatomy in Herbs, Shrubs and Trees. Berlin: Springer-Verlag.

Schweingruber, F. H., Börner, A., Schulze, E.D. 2006. Atlas of Woody Plant Stem: Evolution, Structure, and Environmental modifications. Jena: Springer

Sennblad, B. and Bremer, B. 1996. The Familial and Subfamilial Relationships of and Asclepiadaceae Evaluated Data with rbcL. Plant Systematics and Evolution, 202:153-175.

Silva, N. M. F., Valente, M. C., Pereira, J. F., Filho, G. M. A., Andrade, L. R. 2008. Morfoanatomia de Especies Brasileiras Deoxypetalum (Asclepiadoideae-Apocynaceae). Rodriguésia 59 (4): 915-948
Simpson, M.G. 2006. Plant Systematics. Amsterdam: Elsevier Academic Press.

Singh, G. 1999. Plant Systematics. New Hampshire: Science Publisher.

Sinha, S., Mondal, A. K. 2011. The Morfological Diversification of Pollinia of Some Member of Asclepiadaceae. African Journal of Biotechnology, 10 (41): 7981-7986.

Sivalaya Farm (Flora Café). 2011. Plant Data BasedCosmostigma racemosum. http://floaderacafe.co.in. accessed on 13 December 2011.

Sreedevi, P., Pillai, G. S., Namboodiri, A. N. 1990. Solubility Differences in Sporopollenin of Pollen and Pollinial Walls. Current Science, 59 (6): 324.

Sreenath, K. P., Ramakrishna, T.M., Babu, T. P. 2012. Prespective on Polinial Apparatus and Carriers of Asclepiadaceae sensu lato. Global Journal of Bio-Science and Biotechnology, 1 (1): 45-53.

Stuessy, T. F. 2009. Plant Taxonomy. The Systematic Evaluation of Comparative Data. New York: Columbia University Press.

Swapna, P., Elumalai, A. 2011. Pharmacognostical Evaluation of Calotropis gigantean (Linn). Leaves. International Journal of Pharmacy and Pharmaceutical Sciences, 3(4): 167-174.

The New York Botanical Garden, 2012. Cosmostigma racemosum Wight.

Thomas, M., Hepsibah, P.T.A., Prasad, N.B.R., Kumar, P. S. 1996. Pharmacognostical and Clinical Studies on Wattaka volubilis (Linn.f.). Ancient Science of life, XV: 277-281.

Tjitrosoepomo, G. 2007. Morfologi Tumbuhan. Yogyakarta: Gadjah Mada University Press

Trimen, H. M. D. 1895. A Hand-Book to The Flora of Ceylon. London: Dulau and Co.

Valke, D. 2012.Cosmostigma racemosum. http://www. flickr.com/photos/dinesh_valke/7432478160..

Valente, M. C., Costa, C. G. 2005. Estudo Anatomico Da Flor DeMarsdenia loniceroides E Fournier (AsclepiadoideaeApocynaceae). Rodriguésia, 56 (87): 51-66.

Widodo, Khusnuryani, A., Mufti, F., 2010. Eksplorasi Pola Raunkiaers Life Form dan Kenaekaragaman Major Taxon Vegetasi Puncak Gunung Nglanggeran Gunung Kidul di Tiga Titik Elevasi Jalur Pendakian Utama. Laporan Penelitian.Yogyakarta: Fakultas Saintek UIN Sunan Kalijaga Yogyakarta.

Widodo. 2012. Temuan Specimen Hidup Cosmostigma racemosum di Gunung Nglanggeran Gunung Kidul Yogyakarta. Makalah disajikan dalam Seminar Nasional MIPA dan Pembelajarannya, FMIPA UM Malang, 13 Oktober 2012.

Widodo. 2013. Structure of Fruit Cosmostigma racemosum, Asclepiadoideae of Mountain Nglanggeran Gunungkidul Yogyakarta. Poster presented on International Seminar and Global Resources Conservation. Brawijaya University, February 7, 2013 - February 8, 2013.

Widodo, Amin, M., Al-Muhdar, M. H. I., Luthfi, M. J. 2013. Profil Fitokimia Metabolit Sekunder Cosmostigma racemosum (Asclepiadoideae). Makalah disajikan dalam Seminar Nasional Biodiversitas. Studi, pemanfaatan dan Konservasi keanekaragaman Hayati Nusantara dalam Bidang Kesehatan. UNS, 9 November 2013.

Wight. 1846. Icones Plantarum Orientalis. 1.2 (1). Madras: J. B. Pharoah.

Zhengyi, W., Raven, P. H. 1996. Flora of China. Chicago: Science Press. 